\title{
Electricity Generation by Solar Energy in Turkey: Current State and Outlook
}

\author{
Hasan Yildizhan ${ }^{1}$ and Mecit Sivrioğlu ${ }^{2}$ \\ 1. Faculty of Technology, Iskenderun Technical University, Hatay 31600, Turkey \\ 2. Engineering Faculty, Gazi University, Ankara 6530, Turkey
}

Received: September 10, 2015 / Accepted: October 29, 2015 / Published: December 31, 2015.

\begin{abstract}
Turkey is in good condition in terms of solar energy because of the fact that, Turkey falls in between 40 degree North and 40 degree South latitude which is called as "sunbelt". The potential of producing electric from solar energy is very high in terms of potential of Turkey. According to a report by the Turkish Energy Ministry, Turkey's average rate of electrical energy consumption increased to levels 5.59 in the last 11 years. Moreover, solar energy may be primary energy source on account of the fact that, Turkey is in the position of a country importing energy and has signed Kyoto Protocol of carbon emission to atmosphere. The aim of the article is to give information about acts need to be done and present policies of Turkey on producing electric from solar energy. Beyond question, the policies of the government will determine the direction of developmental momentum of energy industry in Turkey as whole world will. The present support to production of electric from solar energy is not enough, so it is needed to give much higher level of support to this sector. In this context, it is essential to enhance guarantied tariff cost and the power of unlicensed electric production.
\end{abstract}

Key words: Solar energy, incentives, electricity generation, Turkey.

\section{Introduction}

Turkey is in good condition in terms of solar energy potential which renewable because of the fact that, Turkey falls in between 40 degree North and 40 degree South latitude which is called as "sunbelt" and it is in medium-wealth in terms of solar energy. Turkey has an important solar energy potential which has been pending to be evaluated but it has not been done in optimum level, therefore, Turkey is still foreign-dependent. The potential of producing electricity from solar energy has not reached sufficient level owing to bad incentive policies in Turkey. The development of potential of producing electricity from solar energy in Turkey is undoubtedly affected by government policies which we call it as decision makers. According to a report by the Turkish Energy Ministry, Turkey's average rate of electrical energy

Corresponding author: Hasan Yildizhan, assistant professor, research field: energy system engineering. consumption increased to levels 5.59 in the last 11 years. Besides, Turkey has signed the Kyoto Protocol of carbon emission to atmosphere that's why it has to give importance to solar energy. The Kyoto Protocol has been signed in United Nations Framework Convention on Climate Change in 1997, for the purpose of building an international defence mechanism against some problems such as global climate change and warming [1].

The signatory countries have promised to reduce the emission of other five gases causing carbon dioxide and greenhouse effect. Turkey became a party to the Kyoto Protocol with the introduction of participation tool to United Nations on August 26, 2009 after the Council of Ministers' decision no. 2009/14979, date May 13, 2009 and the acceptance of the law no. 5386 which is related to approval of Grand National Assembly for the participation to the Kyoto Protocol linked to United Nations Framework Convention on Climate Change [1]. Therefore, Turkey 
is expected to reduce the carbon dioxide emission for contribution to the targets of global climate change and to give importance to energy sources.

Many writers have stated that, the production of electricity from solar energy depends on government policies of countries [2-8]. Therefore, it is essential for Turkey to implement the optimum incentive policies in order for the jump of the sector related to the production of electricity from solar energy. This paper is deducted and expanded from the previous work [9]. The aim of this paper is to remark Turkey's incentive policies of electricity production with solar energy.

\section{Turkey's Energy Status}

According to a report by the Turkish Energy Ministry [10], at the end of the month of March 2015, Turkey's production and consumption 63.1 billion $\mathrm{kWh}$, 64.4 billion $\mathrm{kWh}$, respectively. Furthermore, according to the same report, Turkey's average rate of electrical energy consumption increased to levels 5.59 in the last 11 years. In addition to that, while electricity consumption 150 billion $\mathrm{kWh}$ in 2004, 1.70 times increased and reached to 255.5 billion $\mathrm{kWh}$ in 2014. On the other hand, due to the economic crisis in 2009, Turkey's electricity generation and consumption according to previous year (2008) has decreased (Table 1 [10]).

While the installation electric power of Turkey was 36,824 MW in 2004, it reached to 69,520 MW in 2014 and this value increased approximately twice to 70,558 MW at the end of March 2015 (Table 1 and Fig. 1 [10]). When Table 2 [10] and Fig. 1 analyzed it can be seen that, installed capacity of solar source activated in 2014. Furthermore installed capacity of solar source rate is $0.09 \%$.

As shown in Table 3 [10], total electricity installed capacity for 2004 hydraulic resources, natural gas, coal sources and wind and geothermal sources comes with share $34.3 \%, 30,8 \%, 22.5 \%$ and $0.1 \%$, respectively. The remaining parts (12.2\%) are formed by other sources. When we want to make a similar assessment at the end of March 2015, it seen while quantity of resources of our country in the amount of installed power unchanged their share in total installed power appeared differences. As of at the end of March 2015, our country's electric power installed capacity consisted of hydraulic resources (34.6\%), natural gas $(30.5 \%)$, coal $(20.8 \%)$ and geothermal + wind + solar (6.0\%) resources, respectively. The share of other sources (outside of these resources) is $8.2 \%$. The largest increase was observed in the share of installed capacity of wind and geothermal resources in the period of March 2004-2015. Furthermore installation of solar based power into the circuit and the private sector to prepare for major investment in this area in 2014 is a great significance in terms of security of supply and diversification of sources Turkey (Table 3). Therefore, it is foreseen that, in the total installed

Table 1 Outlook electricity energy of Turkey (GWh).

\begin{tabular}{lllllll}
\hline Year & Generation & Import & Export & Consumption & $\begin{array}{l}\text { The rate of increase } \\
\text { production }\end{array}$ & $\begin{array}{l}\text { The rate of increase } \\
\text { consumption }\end{array}$ \\
\hline 2004 & 150,698 & 464 & 1,144 & 150,018 & $7.2 \%$ & $6.3 \%$ \\
2005 & 161,956 & 636 & 1,798 & 160,794 & $7.5 \%$ & $7.2 \%$ \\
2006 & 176,300 & 573 & 2,236 & 174,637 & $8.9 \%$ & $8.6 \%$ \\
2007 & 191,558 & 864 & 2,422 & 190,000 & $8.7 \%$ & $8.8 \%$ \\
2008 & 198,418 & 789 & 1,122 & 198,085 & $3.6 \%$ & $-1.8 \%$ \\
2009 & 194,813 & 812 & 1,546 & 194,079 & $-2.0 \%$ & $8.4 \%$ \\
2010 & 211,208 & 1,144 & 1,918 & 210,434 & $8.4 \%$ & $9.4 \%$ \\
2011 & 229,395 & 4,556 & 3,645 & 230,306 & $8.6 \%$ & $5.2 \%$ \\
2012 & 239,497 & 5,826 & 2,954 & 242,370 & $4.4 \%$ & $1.6 \%$ \\
2013 & 240,154 & 7,429 & 1,227 & 246,357 & $0.3 \%$ & $3.7 \%$ \\
2014 & 250,435 & 7,805 & 2,696 & 255,545 & $4.3 \%$ & \\
2015 end of March & 63,143 & 2,146 & 861 & 64,428 & & \\
\hline
\end{tabular}




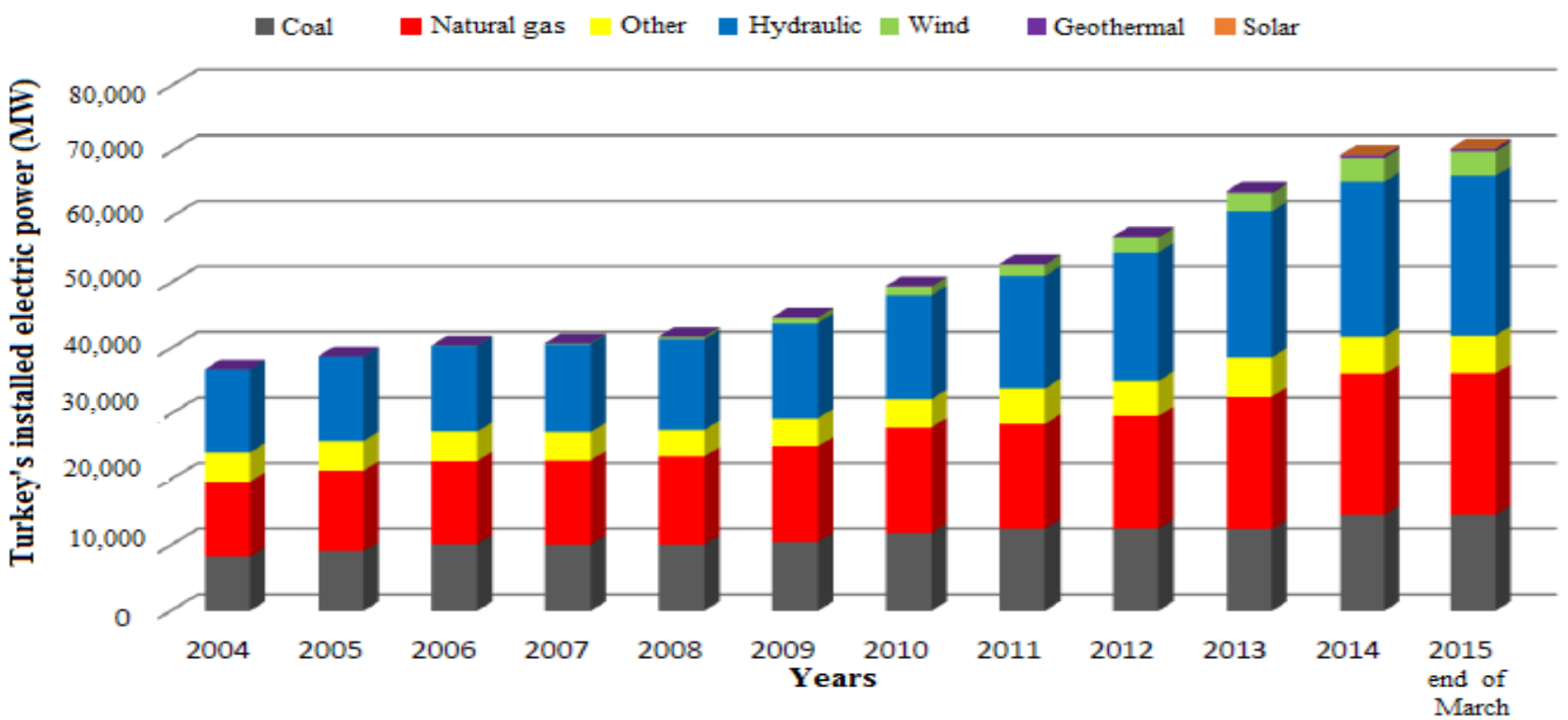

Fig. 1 Electricity installed capacity of Turkey (MW).

Table 2 Turkey electricity installed capacity (MW).

\begin{tabular}{|c|c|c|c|c|c|c|c|c|c|}
\hline \multirow{2}{*}{ Year } & \multicolumn{3}{|c|}{ Thermic } & \multirow{2}{*}{ Hydraulic } & \multirow{2}{*}{ Wind } & \multirow{2}{*}{ Geothermal } & \multirow{2}{*}{ Solar } & \multirow{2}{*}{ Total } & \multirow{2}{*}{ Increase $(\%)$} \\
\hline & Coal & Natural gas & Other & & & & & & \\
\hline 2004 & 8,296 & 11,349 & 4,500 & 12,645 & 18.9 & 15 & - & 36,824 & 3.5 \\
\hline 2005 & 9,117 & 12,275 & 4,487 & 12,906 & 20.1 & 15 & - & 38,820 & 5.4 \\
\hline 2006 & 10,197 & 12,641 & 4,520 & 13,063 & 59 & 23 & - & 40,502 & 4.3 \\
\hline 2007 & 10,097 & 12,853 & 4,322 & 13,395 & 146.30 & 23 & - & 40,836 & 0.8 \\
\hline 2008 & 10,095 & 13,428 & 4,072 & 13,829 & 363.65 & 29.8 & - & 41,817 & 2.4 \\
\hline 2009 & 10,501 & 14,555 & 4,284 & 14,553 & 791.60 & 77.2 & - & 44,761 & 7.0 \\
\hline 2010 & 11,891 & 16,112 & 4,276 & 15,831 & 1,320 & 94.2 & - & 49,524 & 10.6 \\
\hline 2011 & 12,491 & 16,003 & 5,438 & 17,137 & 1,729 & 114.2 & - & 52,911 & 6.8 \\
\hline 2012 & 12,530 & 17,162 & 5,337 & 19,620 & 2,261 & 162.2 & - & 57,072 & 7.9 \\
\hline 2013 & 12,428 & 20,253 & 5,967 & 22,289 & 2,760 & 310.8 & - & 64,007 & 12.2 \\
\hline 2014 & 14,636 & 21,474 & 5,692 & 23,643 & 3,630 & 404.9 & 40.2 & 69,520 & 8.6 \\
\hline $\begin{array}{l}2015 \text { end of } \\
\text { March }\end{array}$ & 14,651 & 21,526 & 5,779 & 24,380 & 3,731 & 427.4 & 63.9 & 70,558 & 1.5 \\
\hline Rate & $20.8 \%$ & $30.5 \%$ & $8.2 \%$ & $34.6 \%$ & $5.3 \%$ & $0.6 \%$ & $0.09 \%$ & $100 \%$ & - \\
\hline
\end{tabular}

Table 3 Ratio of Turkey electricity installed capacity.

\begin{tabular}{llllll}
\hline \multirow{2}{*}{ Year } & \multicolumn{3}{c}{ Thermic } & Hydraulic & Geothermal + wind + solar \\
\cline { 2 - 6 } & Coal & Natural gas & Other & $34.3 \%$ & $0.1 \%$ \\
2004 & $22.5 \%$ & $30.8 \%$ & $12.2 \%$ & $33.2 \%$ & $0.1 \%$ \\
2005 & $23.5 \%$ & $31.6 \%$ & $11.6 \%$ & $32.3 \%$ & $0.2 \%$ \\
2007 & $25.2 \%$ & $31.2 \%$ & $11.2 \%$ & $32.8 \%$ & $0.4 \%$ \\
2008 & $24.7 \%$ & $31.5 \%$ & $10.6 \%$ & $33.1 \%$ & $0.9 \%$ \\
2009 & $24.1 \%$ & $32.1 \%$ & $9.7 \%$ & $32.5 \%$ & $1.9 \%$ \\
2010 & $23.5 \%$ & $32.5 \%$ & $9.6 \%$ & $32.0 \%$ & $2.9 \%$ \\
2011 & $24.0 \%$ & $32.5 \%$ & $8.6 \%$ & $32.4 \%$ & $3.5 \%$ \\
2012 & $23.6 \%$ & $30.2 \%$ & $10.3 \%$ & $34.4 \%$ & $4.2 \%$ \\
2013 & $22.0 \%$ & $30.1 \%$ & $9.4 \%$ & $34.8 \%$ & $4.8 \%$ \\
2014 & $19.6 \%$ & $31.6 \%$ & $9.2 \%$ & $34.0 \%$ & $5.9 \%$ \\
2015 end of March & $21.1 \%$ & $30.9 \%$ & $8.2 \%$ & $34.6 \%$ & $6.0 \%$ \\
\hline
\end{tabular}


capacity of electricity within the solar energy, power production share in Turkey will be an increase in the coming years.

\section{Solar Energy Policies in the World}

The sources of renewable energy have become important due to the ever-growing rise of energy demands of countries and environmental anxieties. Therefore, all countries have steered for the sources of renewable energy in order to reduce carbon emission and make the energy supply sustainable. Most of the countries have incentive policies related to the electricity production from the renewable energy source the sun. Thanks to these policies, the electricity production with solar energy has increased. The installed power of electricity produced from solar energy with PV in 2010 in worldwide is shown in Table 4 [11].

When analyzed, it is seen in Table 1 that, more than $50 \%$ of the PV systems installed in Asian countries are in China and Japan. Moreover, approximately 2/3 of working PV systems in worldwide is in European countries, initially in Spain and Germany as seen in Table 4.

The most common incentive policies applied worldwide is feed-in-tariff application. Well prepared feed-in-tariff incentive mechanism is based on consistent and comprehensive characterisation of the projects on renewable energy sources and careful categorization of renewable energy sources and technologies [12].

Feed-in-tariff is so common in European countries. The country which should be taken as an example for feed-in-tariff is doubtlessly Germany. Feed-in-tariff applied by Germany is provided in Table 5 [13]. Wages are fixed in feed-in-tariff applied in Germany.

Spain comes after Germany in Europe in terms of potential of electricity generation of solar energy. Feed-in-tariff information of Spain is provided in Table 6 [14].

On the other hand, an average of $15 €$ cents $/ \mathrm{kWh}$ in Southern Europe and of $29 €$ cents/kWh in Northern Europe of feed-in-tariff in PV systems was applied in 2010.

\section{Solar Energy Potential of Turkey}

Turkey has a very high potential of solar energy because of its geographical position. According to solar energy potential Atlas of Turkey prepared by the General Directorate of Renewable Energy, it has been

Table 4 Global installed PV capacity in 2010.

\begin{tabular}{llll}
\hline Country & PV capacity $(\mathrm{MW})$ & Country & PV capacity (MW) \\
\hline EU & & North America & \\
Austria & 103 & Canada & 200 \\
Belgium & 803 & USA & 2,528 \\
Bulgaria & 18 & & \\
Czech Republic & 1,953 & APEC & \\
France & 1,025 & Australia & 504 \\
Germany & 17,193 & South Korea & 655 \\
Greece & 206 & Taiwan & 22 \\
Italy & 3,494 & Thailand & 10 \\
Portugal & 130 & & \\
Slovakia & 145 & Japan & 3,622 \\
Spain & 3,784 & China & 893 \\
United Kingdom & 66 & India & 102 \\
Rest of the EU & 333 & Rest of the world & 1,742 \\
EU total & 29,253 & World total & 39,531 \\
\hline
\end{tabular}

\footnotetext{
Asia-Pacific economic cooperation.
} 
Table 5 Feed-in tariffs values and digression rate for electricity generated from PV systems in Germany.

\begin{tabular}{|c|c|c|c|c|c|c|c|c|c|c|}
\hline \multirow{3}{*}{ FIT } & \multicolumn{8}{|c|}{ Rooftop } & \multirow{2}{*}{\multicolumn{2}{|c|}{$\begin{array}{l}\text { Ground-mounted } \\
\text { installations } \\
\text { All sizes }\end{array}$}} \\
\hline & \multicolumn{2}{|c|}{$P \leq 30 \mathrm{kWp}$} & \multicolumn{2}{|c|}{$30<P \leq 100 \mathrm{kWp}$} & \multicolumn{2}{|c|}{$100<P \leq 1,000 \mathrm{kWp}$} & \multicolumn{2}{|c|}{$P>1,000 \mathrm{kWp}$} & & \\
\hline & $\begin{array}{l}\text { Digression } \\
\text { rate }(\%)\end{array}$ & $€ / \mathrm{kWh}$ & $\begin{array}{l}\text { Digression } \\
\text { rate }(\%)\end{array}$ & $€ / \mathrm{kWh}$ & $\begin{array}{l}\text { Digression } \\
\text { rate }(\%)\end{array}$ & $€ / \mathrm{kWh}$ & $\begin{array}{l}\text { Digression } \\
\text { rate }(\%)\end{array}$ & $€ / \mathrm{kWh}$ & $\begin{array}{l}\text { Digression } \\
\text { rate }(\%)\end{array}$ & $€ / \mathrm{kWh}$ \\
\hline 2009 & 8 & 0.43 & 8 & 0.40 & 10 & 0.39 & 25 & 0.33 & 10 & 0.31 \\
\hline 2010 & 8 & 0.39 & 8 & 0.37 & 10 & 0.35 & 10 & 0.29 & 10 & 0.28 \\
\hline 2011 & 9 & 0.36 & 9 & 0.34 & 9 & 0.32 & 9 & 0.27 & 9 & 0.26 \\
\hline
\end{tabular}

Table 6 Spanish PV feed-in tariff in 2011.

\begin{tabular}{ll}
\hline Type & Feed-in tariff $(€ / \mathrm{kWh})$ \\
\hline Rooftop \& facades $<20 \mathrm{~kW}$ & 0.281 \\
Rooftop \& facades $>20 \mathrm{~kW}<2 \mathrm{MW}$ & 0.198 \\
Remainder (ground-mounted) $<10 \mathrm{MW}$ & 0.130 \\
\hline
\end{tabular}

determined that, the annual sunshine time is $2,737 \mathrm{~h}$ (a total of $7.5 \mathrm{~h}$ per day), the total annual solar energy is $1.527 \mathrm{kWh} /\left(\mathrm{m}^{2}\right.$.year) (a total of $4.2 \mathrm{kWh} / \mathrm{m}^{2}$ per day) [13]. For this reason, Turkey has a significant solar energy potential waiting to be evaluated. Therefore, the potential to obtain electricity from solar energy in Turkey is high. Solar energy potential map of Turkey is provided in Fig. 2 [15].

The monthly and regional solar energy potentials with sunshine durations of Turkey are shown in Table 5 and Table 7 [16].

The biggest radiant intensity and sunshine duration in Turkey as seen in Table 7 is in July.

The biggest radiant intensity and sunshine duration in Turkey as seen in Table 8 [16] is in South Eastern Anatolia.

\section{Turkey's Current Solar Energy Policy}

According to the estimation of International Energy Agency, among the EU member countries, it has been noted that, Turkey will be the country, in which the energy demand will significantly develop in the fastest manner - in the mid term and in the long run [17]. Due to considerable energy demand of Turkey, it is compulsory that, she must put forth her energy policies in the most appropriate manner. In this context, in the Turkey's energy strategy document proclaimed by Turkey's Foreign Affairs Ministry, it was made known: that Turkey will aim to abate her dependence of foreign energy sources, that she will increase the usage of her local sources in the maximal level-and by embarking the way with the targets of combating the climate change, she will increase the share of the renewable sources in the national energy demand portfolio [18]. With this document, Turkey has declared her target of increasing the share of renewable energy in the energy conglomeration. The incentives allocated according to the 6,094 numbered law regarding the use of solar energy for the production of electricity are shown in Tables 9 and 10 [19].

When Tables 9 and 10 are investigated, it was made to be known that, there will be fixed price guarantee at 13.3 (USA dollar cent $/ \mathrm{kWh}$ ) in the electricity production with solar energy and there will be additional incentives for the local equipments to be used in electricity production with the solar energy. As seen in Table 11, with the additional incentives, the maximum contribution to be given for the electricity production with the solar energy is between 20 and 23 (USA dollar cent/kWh) [19]. On the other hand, in Turkey, maximum production power without a licence has to be at $1 \mathrm{MW}$ capacity. In the meantime, there is not a pricing, in Turkey, according to the installed power of the electricity production from solar energy. Therefore, in Turkey, there is only one price application. Namely, the incentive given for generating $30 \mathrm{~kW}$ electricity from solar energy and for the production of $1 \mathrm{MW}$ electricity is same, at the level of $13.3 \mathrm{USD}$ cent $/ \mathrm{kWh}$. 


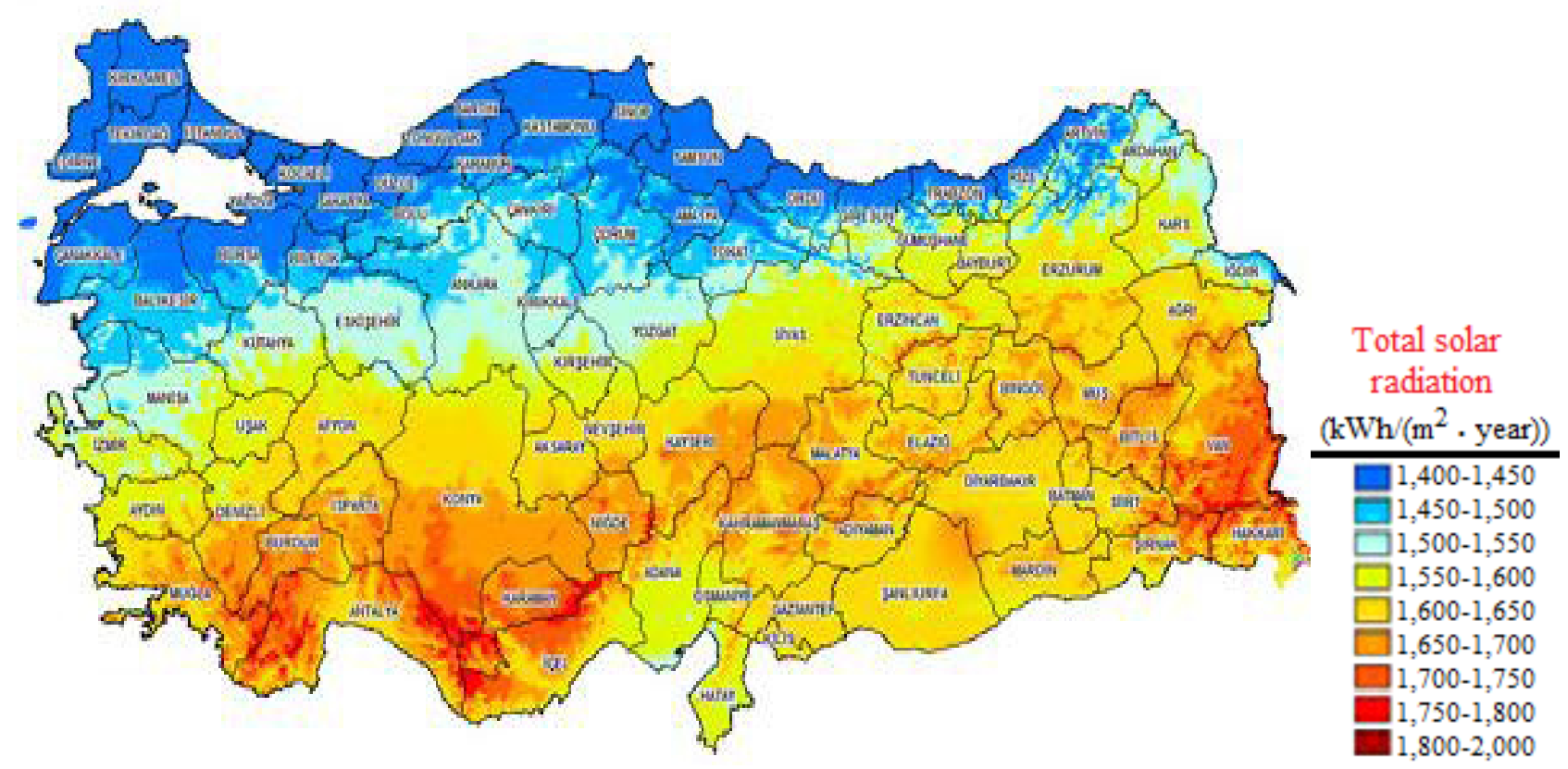

Fig. 2 Atlas of solar energy potential in Turkey.

Table 7 Monthly average solar energy potential of Turkey.

\begin{tabular}{|c|c|c|}
\hline Month & Monthly total solar radiation $\left(\mathrm{kWh} /\left(\mathrm{m}^{2} \cdot \mathrm{month}\right)\right)$ & Sunshine duration (h/month) \\
\hline January & 59.7 & 106.9 \\
\hline February & 76.6 & 135.2 \\
\hline March & 116.8 & 170.2 \\
\hline April & 139.1 & 203.5 \\
\hline May & 171.5 & 260.5 \\
\hline June & 186.9 & 318.1 \\
\hline July & 193.4 & 339.3 \\
\hline August & 174.8 & 322.3 \\
\hline September & 140.3 & 277.9 \\
\hline October & 100.0 & 200.6 \\
\hline November & 64.7 & 142.0 \\
\hline December & 50.0 & 96.3 \\
\hline Total & $1,473.8$ & $2,572.8$ \\
\hline Average & $4 \mathrm{kWh} /\left(\mathrm{m}^{2} \cdot\right.$ day $)$ & $7 \mathrm{~h} /$ day \\
\hline \multicolumn{3}{|c|}{ Regional solar energy potential of Turkey. } \\
\hline Region & Monthly total solar radiation $\left(\mathrm{kWh} /\left(\mathrm{m}^{2} \cdot \mathrm{month}\right)\right)$ & Sunshine duration (h/month) \\
\hline Southeastern Anatolia & 1,648 & 2,845 \\
\hline Mediterranean & 1,548 & 2,737 \\
\hline East Anatolia & 1,523 & 2,519 \\
\hline Central Anatolia & 1,481 & 2,563 \\
\hline Aegean & 1,528 & 2,615 \\
\hline Marmara & 1,329 & 2,250 \\
\hline Black Sea & 1,305 & 1,929 \\
\hline
\end{tabular}


Table 9 The incentive given for the production facilities for the electricity energy generation, according to the 6,094 numbered law.

\begin{tabular}{ll}
\hline Scale number I (it has been decreed with the 29/12/2010 dated and 6,094 numbered law) & \\
\hline The type of production facility based on renewable energy source & $\begin{array}{l}\text { The rates to be applied } \\
\text { (USA dollar cent } / \mathrm{kWh} \text { ) }\end{array}$ \\
\hline a. Production facility based on solar energy & 13.3 \\
\hline
\end{tabular}

Tablo 10 The incentives given when the solar energy systems are formed within the country, according to the 6,094 numbered law.

\begin{tabular}{|c|c|c|}
\hline \multicolumn{3}{|c|}{ Scale number II (it has been decreed with the 29/12/2010 dated and 6094 numbered law) } \\
\hline Facility type & Production within the country & $\begin{array}{l}\text { Local additional contribution } \\
\text { (USA dollar cent } / \mathrm{kWh} \text { ) }\end{array}$ \\
\hline \multirow{5}{*}{$\begin{array}{l}\text { A. Photovoltaic production } \\
\text { facility based on solar } \\
\text { energy }\end{array}$} & 1. PV panel integration and production of solar mechanical structures & 0.8 \\
\hline & 2. PV modules & 1.3 \\
\hline & 3. Cells forming the PV module & 3.5 \\
\hline & 4. Invertor & 0.6 \\
\hline & 5. Material focusing the solar beam on PV module & 0.5 \\
\hline \multirow{7}{*}{$\begin{array}{l}\text { B. Production facility based } \\
\text { on concentrated solar energy }\end{array}$} & 1. Radiation receiving tube & 2.4 \\
\hline & 2. Reflecting surface plate & 0.6 \\
\hline & 3. Solar tracking system & 0.6 \\
\hline & 4. Mechanical accessory of heat energy storage system & 1.3 \\
\hline & $\begin{array}{l}\text { 5. By catching the solar beams on the tower, the mechanical accessory } \\
\text { of the steam production system }\end{array}$ & 2.4 \\
\hline & 6. Stirling engine & 1.3 \\
\hline & 7. Panel integration and the structural solar panel mechanics & 0.6 \\
\hline
\end{tabular}

Tablo 11 The highest possible incentive amount in the totality, according to 6,094 numbered law.

\begin{tabular}{llll}
\hline Facility type & Scale 1 & $\begin{array}{l}\text { Scale 2: contribution (the highest value } \\
\text { possible to be gained according to the } \\
\text { production taking place within country) }\end{array}$ & $\begin{array}{l}\text { The highest value in total } \\
\text { (dollar cent } / \mathrm{kWh)}\end{array}$ \\
\hline Solar photovoltaic & 13.3 & 6.7 & 20 \\
Concentrated solar beam & 13.3 & 9.2 & 22.5 \\
\hline
\end{tabular}

\section{Conclusions and Proposals}

It is inevitable that, Turkey must, immediately, make the necessary amendments in her legislation, without further being late, in order to contribute Turkey's global climate change targets, to avail the great solar energy potential she has and to alleviate the cost of imported energy which is the biggest budget item in the foreign trade deficit.

For this, as in the Germany example, it will be beneficial if the existing fixed guarantee tariff pricing is done, according to the installation power. The guarantee cost rates Turkey applies are lower than the average in Europe. For this reason, guarantee tariff rates must be raised. Also, Turkey's being given incentives towards the goal of enhancing the electricity production power is inevitable for the sector to develop.

\section{References}

[1] Üstün, A. K., Apaydın, M., Filik, Ü. B., and Kurban, M. 2009. "Turkey under the Kyoto Protocol Overview of Renewable Energy Policy." In Proceedings of the 5th Symposium on Renewable Energy Sources, 23-9.

[2] Burns, J. E., and Kang, J. S. 2012. "Comparative Economic Analysis of Supporting Policies for Residential Solar PV in the United States: Solar Renewable Energy Credit (SREC) Potential." Energy Policy 44 (May): 217-25.

[3] Hosenuzzaman, M., Rahim, N. A., Selvaraj, J., Hasannuzzaman, M., Malek, A. B. M. A., and Nahar, A. 2015. "Global Prospects Progress Policies and Environmental Impact of Solar Photovoltaic Power Generation." Renewable and Sustainable Energy Reviews 41 (January): 284-97. 
[4] Jordan, P. G. 2014. "Global Solar Policy." In Solar Energy Markets. London: Elsevier, 43-64.

[5] Govinda, R., Kurdgelahvili, L., and Patrick, A. N. 2012. "Solar Energy: Markets, Economics and Policies." Renewable and Sustainable Energy Reviews 16 (1): 449-65.

[6] Solangi, K. H., Saidur, I. R., Rahim, N. A., and Fayaz, H. 2011. "A Review on Global Solar Energy Policy." Renewable and Sustainable Energy Reviews 15 (4): 2149-63.

[7] Sener, C., and Fthenakis, V. 2014. "Energy Policy and Financing Options to Achieve Solar Energy Grid Penetration Targets: Accounting for External Costs." Renewable and Sustainable Energy Reviews 32 (April): 854-68.

[8] Pegels, A., and Lütkenhorst, W. 2014. "Is Germany's Energy Transition a Case of Successful Green Industrial Policy? Contrasting Wind and Solar PV." Energy Policy 74 (11): 522-34.

[9] Yildizhan, H., and Sivrioğlu, M., 2014. "Solar Energy Policies of Turkey." In Proceedings of the Solar Conference \& Exhibition, 238-43.

[10] Republic of Turkey Ministry of Energy and Natural Resources. 2015. "Energy and Natural Resources View our World and Country.” Republic of Turkey Ministry of Energy and Natural Resources.

[11] EPIA (European Photovoltaic Industry Association). 2011. "Global Market Outlook for Photovoltaics Until 2015." EPIA.

[12] Jacobsson, S., and Lauber, V. 2006. "The Politics and
Policy of Energy System Transformation-Explaining the German Diffusion of Renewable Energy Technology." Energy Policy 34 (3): 256-76.

[13] Paul, G. 2011. Renewable Energy Tariffs in Europe and Elsewhere. California: Wind-Works.org by Paul Gipe. Accessed November 20, 2011. http://www.wind-works.org/articles/feed laws.html.

[14] NREL (National Renewable Energy Laboratory). 2011. Innovative Feed-in Tariff Designs That Limit Policy Costs. Technical report.

[15] Republic of Turkey Ministry of Energy and Natural Resources, Accessed: August 5, 2014. http://repa.eie.gov.tr/MyCalculator/Default.aspx.

[16] Sensoy, S., Ulupınar, Y., Demircan, M., Alan, İ., Akyurek, Z., and Bostan, P. A. 2010. "Modeling Solar Energy Potential in Turkey." Presented at the Conference on Water Observation and Information System for Decision Support, 2010, Ohrid, Republic of Macedonia.

[17] IEA (International Energy Agency). 2009. "Energy Policies of IEA Countries-Turkey 2009 Review." IEA. Accessed August 10, 2014. http://www.iea.org/countries/membercountries/turkey/.

[18] Republic of Turkey Ministry of Foreign Affairs. 2014. “Turkey’s Energy Strategy.” Republic of Turkey Ministry of Foreign Affairs. Accessed August 20, 2014. http://www.mfa.gov.tr/turkiye_nin-enerji-stratejisi.tr.mfa.

[19] Deren Law Office. 2011. "Renewable Energy Sources for Electricity Law No. 6094 Amending the Law on the Use of Production." Official Newspaper, August 1. Issue: 27809. 